\title{
Hyperalgesia and Sensitization of Cutaneous Polymodal Receptors Induced by Clioquinol in Rats
}

\author{
Shigeyuki Suzuki, Jun Sato, Kazue Mizumura and \\ Takao Kumazawa \\ Department of Neural Regulation, Research Institute of Environmental Medicine, \\ Nagoya University, Nagoya, Japan
}

(Received 26 June 1995)

\begin{abstract}
We have shown that clioquinol (CQ) excited and sensitized visceral nociceptors activities ${ }^{1,2)}$. The first of the present studies evaluated the CQ effect on pain bebavior of rats. CQ $100 \mu \mathrm{M}(0.1 \mathrm{~m} l$ in $1 \%$ DMSO diluted with saline) was injected sc. into the foot pad. Withdrawal latency measured by immersion in a $47^{\circ} \mathrm{C}$ water was reduced to $50 \%$ by CQ lasting 7 hours. In the second study, single cutaneous polymodal receptor (CPR) activities were recorded from saphenous nerve of anesthetized rats. CQ $(100 \mu \mathrm{M})$ injection to the receptive field induced intermittent, burst-like discharges and sensitized heat response of CPRs. These results showed that CQ can induce hyperalgesia in the rats and abnormal activities and sensitization of cutaneous pain receptors.
\end{abstract}

Key words: SMON (Subacute Myelo-Optico-Neuropathy), clioquinol, polymodal receptor, pain behavior

キノホルムによるラットの皮膚痛覚過敏現象と皮膚ポリモーダル受容器の興奮

鈴木 重行 佐藤 純 水村 和枝 熊澤 孝朗

名古屋大学環境医学研究所 神経性調節分野

はじめに

各種病態にみられる痛みの成因に，末梢の痛覚受 容器の異常放電が関与していることが明らかになり つつある ${ }^{3,4)}$. キノホルム中毒として知られるスモン に伴う痛みにおいても，その痛みの性質 ${ }^{5}$ からポリ モダール受容器の異常放電が関与している可能性が
示唆されている.我々はスモンの原因物質であるキ ノホルム (clioquinol) が，内臟のポリモーダル受容 器の異常放電を引き起こし, その薬物, 熱刺激に対 する反応を増強させることを明らかにしてい $ろ^{1,2)}$. 今回, キノホルムの末梢への局所投与が動物 の痛み逃避行動に及ぼす影響と，皮膚ポリモーダル 受容器の神経活動に対する効果について検討した。 


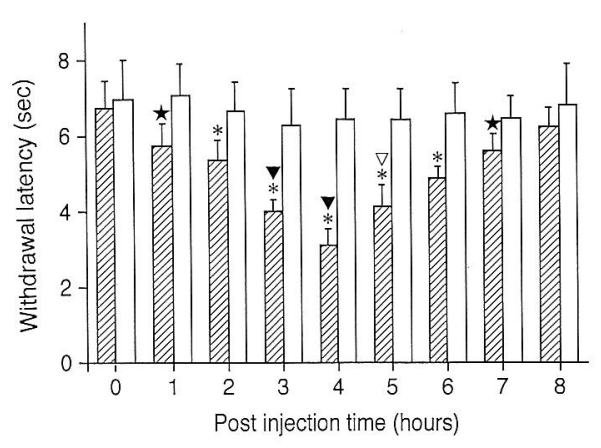

Fig. 1 Clioquinol 投与ラットの熱刺激に対する逃 避行動潜時とその経時的変化.

縦軸は $47^{\circ} \mathrm{C}$ の温水に足部を浸したとき にみられる逃避行動の潜時 (秒), 横軸は薬 物皮下注射後の経過時間を示す. 10 秒以上 逃避行動がみられなかった場合はそれ以上 の刺激は行わず，すべて 10 秒として計測し た. $\square$; DMSO 投与群 $(\mathrm{n}=6$, 対照群), 巴 ; clioquinol 投与群 $(\mathrm{n}=8)$, (mean $\pm S E)$. Clioquinol 群の逃避潜時は投与前に比べ 1 時間後より有意な短縮がみられ, 投与後 4 時 間で最短となった。その効果は 7 時間後まで 持続した (ANOVA, Fisher's PSLD, „; $\mathrm{p}<0.05, * ; \mathrm{p}<0.01)$. また clioquinol 群は DMSO 群に比べ投与後 3 時間後より有意な 短縮がみられ,その効果は 5 時問後まで持続 した (Mann-Whitney U test, $\nabla ; \mathrm{p}<0.05$, $\boldsymbol{\nabla} ; \mathrm{p}<0.01)$.

\section{方 法}

\section{1. 痛み逃避行動テスト}

14 匹の SD オスラットの後肢足背部に, $0.1 \mathrm{~m} l$ の clioquinol（CQ） $100 \mu \mathrm{M}$ 溶液または対照群として DMSO (Dimethyl Sulfoxide) $0.2 \%$ 溶液を $27 \mathrm{G}$ の注 射針を用いて注入後,熱刺激テストを 60 分毎に行っ た。熱刺激としては $47^{\circ} \mathrm{C} に$ 加温した温水に後肢足 部を浸すこととし，逃避行動が起こるまでの時間を 計測し，それを逃避潜時とした. 10 秒たっても逃避 行動を示さない場合は, 熱傷をさけるためその時点 で中止した.

\section{2. 単一神経放電記録実験}

SD ラットを深麻酔（ウレタン $1.0 \mathrm{~g} / \mathrm{kg}$, iv) 後, 大腿部内側に作成したパラフィンオイルプール内に

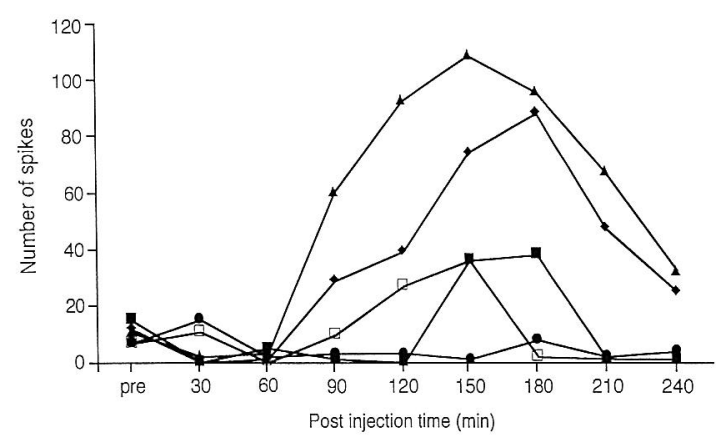

Fig. 2 皮膚痛覚受容器の熱反応に対する clioquinol 投与の影響とその経時的変化。

縦軸は 1 回の熱刺激中に出現した総イン パルス数,横軸は薬物皮下注射後の経過時間 を示す。ポリモーダル受容器ユニット5例の 反応の経過をそれぞれ折れ線で示した。ユニ ット5 例中 4 例に扔いて 150〜180 分をピー クとする反応の増強がみられた。

おいて伏在神経を用い実験を行った，下腿または足 背部に受容野を持つC 線維ポリモーダル受容器 (CPR) の単一神経放電を伏在神経の微小神経束か ら記録した ${ }^{3)}$. 伝導速度は, 記録電極より末梢側にお いた刺激電極による電気刺激に対する興奮の伝導時 間と，刺激電極，記録電極間の距離から算出した.

導出した CPRの受容野の皮下に $0.1 \mathrm{~m} l$ の CQ $(100 \mu \mathrm{M})$ 溶液，または対照群として DMSO (0.2\%) 溶液を $27 \mathrm{G}$ の注射針を用いて注入し，それらの CPR 放電活動に対する効果を比較した。また，受容 野に対する輻射熱刺激を 30 分間隔で行い,誘発され る放電数に対する薬物投与の効果を比較検討した。 熱刺激は, 基礎温度 $34^{\circ} \mathrm{C}$ 加 2 秒間比 $2^{\circ} \mathrm{C}$ 上昇, 5 秒維持の繰り返しステップ刺激とし,1 ステップに 5 インパルス以上出現するまで絽り返した（ピーク 温度). 熱刺激 2 回目からは誘発される放電数に関 わらず, ピーク温度までの刺激とした。

\section{結 果}

\section{1、痛み逃避行動テスト}

結果を Fig. 1 亿示す. DMSO または CQ 投与前の 熱刺激に対する逃避行動潜時はそれぞれ $7.0 \pm 1.1$ 


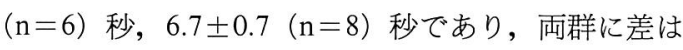
みられなかった. DMSO 投与後の逃避行動潜時は投 与後 8 時間に至るまで変化しなかった。一方, $\mathrm{CQ}$ 投 与群では投与後 1 時間より短縮傾向がみられ，その 程度は投与後 4 時間において最大となった。その後 の回復は徐々に起こり, 投与後 8 時間には投与前の レベルまで戻った。

\section{2. 単一神経放電記録実験}

3 例のユニットに対して DMSO 投与を行ったが， 受容器放電が誘発されることはなかった。また 30 分 間隔の熱刺激に対する反応に及ぼす影響をみたが， 増強することはなかった。一方，5例において $\mathrm{CQ} 100 \mu \mathrm{M}$ の皮下投与を行ったが，2 例において明 らかな誘発放電が観察された。その潜時は平均 4.5

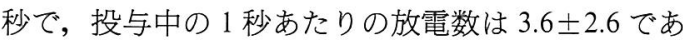
つた。この誘発放電は約 10 分続いた。また，5例に おいて熱反応に対する効果を調べた。その結果を

Fig. 2 に示す. 3 例において CQ 投与後 90 分後から 熱反応の増強がみられ,そのピークは 150〜180 分で あった，その後反応は減少傾向を示したが，増強効 果は 240 分まで続いた。他の 2 例においても，その 程度は少ないが同様の時間経過での增強がみられ た。

\section{考察}

今回, clioquinol の皮下投与は熱刺激による逃避 行動の潜時を有意に短縮せしめた。さらに, 皮膚ポ リモーダル受容器の単一神経放電記録により, clioquinol が受容器ユニットの熱反応を有意に増強す ることがわかった。これらの事実から，スモンの原 因物質である clioquinol が痛覚受容器の熱反応性を 高めたことにより, 逃避行動の潜時短縮を引き起こ したものと考えられる。痛覚受容器の感作は投与後 90 分よりみられ, 150〜180 分で最高となり，その後 漸減した。一方, 逃避行動においては cliquinol の効 果は 60 分から出現し, 4 時間で最高となり投与後 7 時間まで続くものであった。両者の時間的経過に差
異がみられた理由は明らかではない.

Clioquinol 投与により 5 例中 2 例のポリモーダ ル受容器に異常放電が観察された。この結果は内臓 ポリモーダル受容器において観察された結果を支持 するものである1). しかしながらその程度は後者に 比べ低かった。これは，投与法の違いによるものと も考えられるが詳細は不明である。

今回，スモンの原因物質である clioquinol によっ てラットに痛覚過敏が引き起こされ, そのメカニズ ムにはポリモーダル受容器の感作が関係しているこ とが示唆された。以上の結果は，スモンにみられる 痛みの成因に皮䖉ポリモーダル受容器が関与してい る可能性を示すものと考えられる。

\section{文献}

1) Kumazawa, T. and Mizumura, K., Abnormal activity of polymodal receptors induced by clioquinol (5-chloro-7-iodo-8-hydroxyquinoline), Brain Res., 310 (1984) 185-188.

2) Kumazawa, T., Koda, H. and Mizumura, K., Influences of clioquinol on the heat response of viscera! polymodal receptors, Annual Report of the Research Committee of SMON, The Ministry of Health and Welfare of Japan, 1992, pp. 96100. (in Japanese)

3) Sato, J. and Perl, E. R., Adrenergic excitation of cutaneous pain receptors induced by peripheral nerve injury, Science, 251 (1991) 1608-1610.

4) Sato, J., Suzuki, S., Iseki, T. and Kumazawa, T., Adrenergic excitation of cutaneous nociceptors in chronically inflamed rats, Neurosci. Lett, 164 (1993) 225-228.

5) Sobue, I., Clinical aspects of subacute myelooptico-neuropathy (SMON). In : J. Vinken and G. W. Bruym (Eds.), Handbook of Clinical Neurology, vol. 37, North Holland Publishing Co., Amsterdam, 1979, pp. 115-139.

Address for correspondence: Takao Kumazawa, M. D., Department of Neural Regulation, Research Institute of Environmental Medicine, Nagoya University, Furo-cho, Chikusa, Nagoya 464-01, Japan.

Tel : 052-789-3861

Fax : 052-789-3887 